\title{
Visuality, Coloniality and Modernism in the Gran Chaco: Assessing Grete Stern's indigenous photographs.
}

Ignacio Aguiló

In recent years, Grete Stern's series of photographs of indigenous people from northern Argentina's Chaco region have been the subject of increasing attention. Most critics argue that in these images it is possible to find one of the best examples of the convergence of her humanist concerns with the fate of oppressed and persecuted people and her modernist approach to photography. Consequently, a narrative is put forward that connects Stern's earlier experiences both as a Jew during the rise of Nazism and as an exponent of the Bauhaus style, with her representations of indigenous people. The aim of this article is to suggest a more complex study of this photographic series, mainly by shifting the focus of analysis from Stern's figure to the photographs themselves, therefore locating them in relation to previous and subsequent visual representations of Argentina's indigenous cultures. Firstly, I will examine up to what extent these photographs introduce an aesthetic and ethical break with the visuality of the Gran Chaco produced by late nineteenth-and early twentiethcentury anthropology, in line with the occupation of this region by the national state. Secondly, I will analyze how they contributed to a shift towards an increasing aestheticization of indigenous communities, aestheticization that would go on to be recuperated and influence the work of contemporary photographers. This aspect will be the focus of the last section of this article, taking Guadalupe Miles's series Chaco as a case study.

Grete Stern's photographs of indigenous people from the Gran Chaco region, taken between 1958 and 1964, have been the subject of increasing attention in recent years. This is exemplified by exhibitions at Fundación Proa in Buenos Aires in 2005 and at Berlin Ethnological Museum in 2010-11, and by the publication in 2005 of Aborígenes del Gran Chaco. Fotografias de Grete Stern (Indigenous People of the Gran Chaco: Photographs by Grete Stern), a book that includes a selection of Stern's images and a critical study by renowned photography historian Luis Priamo, along with texts on indigeneity by well-known anthropologists José Antonio Pérez Gollán and Pablo Wright. Most critics argue that Stern's Chaco images can be seen as the quintessential convergence of her aesthetic and ethical ideas and concerns: on the one hand, the modernist approach to photography; on the other, the humanist preoccupation with the fate of oppressed and persecuted people. Priamo (2005) argues that this group of photographs 'is unique in her [Stern's] extensive and varied oeuvre. As a document it is also coherent with her ethical and artistic principles.' (163) This 
interpretation is therefore instrumental in articulating a particular narrative that connects these representations of indigenous people with Stern's earlier experiences, both as a Jew during the rise of Nazism and as an exponent and introducer of the Bauhaus style in Argentina. The aim of this article is to suggest a more complex study of this photographic series, mainly by shifting the focus of analysis from Stern's figure to the photographs themselves, therefore locating them in relation to previous and subsequent visual representations of indigenous cultures. In order to do this, I will first examine up to what extent these images introduce a rupture with the visuality of the Gran Chaco produced by late nineteenth- and early twentieth-century anthropology, in line with the colonization of this region by the national state. Secondly, I will analyze how they contributed to an aestheticization of chaqueño indigenous communities - aestheticization that would go on to be recovered by and influence the work of contemporary photographers working on indigeneity in northern Argentina. The last section of this article will focus on this aspect, and particularly on how the virtues and contradictions present in Stern's photographs are addressed in Guadalupe Miles's work Chaco, produced at the turn of the twenty-first century.

In order to understand the relevance of Stern's project, it is important to trace a brief genealogy of the visuality of chaqueño indigeneity, which also implies understanding the place of the Gran Chaco in the Argentine imaginary of race. The Gran Chaco is a great plain of over 600,000 square kilometers that combines low elevations and moderate depressions, covering areas of Argentina, Bolivia, and Paraguay. It spans from the Paraguay and Paraná rivers on the east to the Andean foothills on the west, and from the Salado River basin on the south to the Mato Grosso plateau on the north. The native population of Chaco has been traditionally classified according to six main linguistic groups: Mataco-maká (Wichí-Mataco, Chorote, Nivaclé-Chulupí, Maká), Guaycurú (Toba, Toba-Pilagá, Pilagá, Mocoví, MbayáCaduveo), Lule- Vilela (Chunupí), Lengua-Maskoi (Lengua, Sanapaná, Angaité, Enenlhet), Zamuco (Chamacoco-Ishir, Ayoreo) and Tupi-Guaraní (Ava-Chiriguano, Chané, Tapiete, Isoseño-Guaraní, and Guaraní Occidental) (Combes, Villar, and Lowrey 2009). ${ }^{1}$ Prior to the arrival of Europeans, different migrations from the Pampas, the Amazon basin, and the Andes had shaped and re-shaped Chaco's cultures for centuries. The fact that chaqueño indigenous groups were not an easy source of labor force, combined with the lack of gold and silver in the region, implied that during the time of the Spanish Empire the area remained a very low priority for the Crown (Gordillo 2006a, Braunstein and Miller 1999). This situation did not experience much transformation in the aftermath of the independence war, and although the 
growth of sugar cane industry started to put pressure on chaqueño indigenous communities, they continued to live in relative autonomy (Gordillo 2006a). The progressive consolidation of the modern Argentine nation-state in the second half of the nineteenth century altered this situation, given that the expansion of the capitalist frontier and the definition of geopolitical borders were key priorities for the nation-building elites (Viñas 2013). In 1884, shortly thereafter the conclusion of the Conquista del desierto, the state launched a fully-fledged military campaign that succeeded in occupying the southern Chaco and seriously undermined indigenous resistance. In the following years, successive military campaigns, the growth of sugar plantations and sawmills, and the promotion of white settlements affirmed state sovereignty and capitalist expansion over the Argentine Chaco, and seriously deteriorated indigenous people's traditional livelihoods. ${ }^{2}$

Aníbal Quijano (2000) defines the coloniality of power as the modern structures of power and control developed with the colonization of America. According to him, two axes constitute the central articulators of these structures: race and capital.

All the forms of labor, production and exploitation were in ensemble around the axis of capital and the world market: slavery, serfdom, petty commodity production, reciprocity and salary [...] At the same time, in the same historical movement, and for the first time in the history of humankind, along with America there was produced a new mental category to codify the relations between conquering and conquered populations: the idea of 'race', as biologically structural and hierarchical differences between the dominant and the dominated. (216)

This concept is useful to consider the case of the Chaco, in which the racialization and proletarization of indigenous communities converged as part of the colonization of Argentina's 'internal' frontiers. In this article, the reference to 'colonial situation' predominantly addresses the condition of indigenous communities after their subjugation by the Argentine state, as an expression of this coloniality of power. A central element in this process of colonial advance was the instrumentalization of scientific knowledge, in particular the emerging field of anthropology (Gordillo 2005, Lois 2002). In fact, the Gran Chaco and the chaqueño Amerindian occupied a crucial role in the development of anthropological discourse in Argentina, as both were constructed as images of a radical alterity on which 
ideas about biological racism could be projected. ${ }^{3}$ What is more important, the dynamics of colonial power relationships implied that this projection was also instrumental in the very same constitution and consolidation of the identity of the modern Argentine nation as white/Europeanized. Narratives of whiteness would go on to constitute defining articulators of national identity in Argentina in the twentieth century. The Gran Chaco and its indigenous communities, consequently, were organized according to an imaginary of otherness that provided further legitimacy to the nation-building project of the Argentine elites, founded on whitening and capitalism. By framing colonial expansion in terms of an enterprise of redemption, the Argentine elites could position themselves as local executors of the mission to which the white race was obliged, at a time in which scientific racism was at its height.

It is pertinent, at this stage, to briefly examine the articulation of race and visuality, and how this was subsequently deployed in the colonization of the Chaco. In the late eighteenth and early nineteenth centuries, the emergence of modern physiognomy in Europe transformed the human body into a materiality ready for formal reading and examination, giving way to the elaboration of modern theories of racial difference. Its development into a principle of equivalence and categorization centered on the notion of 'type' contributed to this, by establishing the idea that phenotypical variation was a signifier of race. This was a difference that could be organized to the point that each subject was deemed representative of all the attributes of a specific race and comparable to others within the same racial group. Photography legitimized these notions thanks to its alleged transparency and realism, and provided with a format on which the logic of typification and quantification was a 'visible' reality (Poole 1997, Edwards 1990). Simultaneously, it disseminated and popularized biological racism through the circulation and consumption of representations of non-white people within a transnational visual economy of race. In this sense, we can see the development of photography as a specific technology of visuality, in the sense the term is used by Nicholas Mirzoeff (2010); that is, as a modality composed of three operations: first, naming and classification - a process that he compares to Michel Foucault's 'nomination of the visible', and to which could be added, following the previous discussion, typification. Secondly, the segregation of the groups so classified, in order to prevent their selfconstitution as coherent political subjects. Thirdly, the portrayal of this classification as right and hence aesthetic. 'Classifying, separating, and aestheticizing together form what I shall call a complex of visuality.' (Mirzoeff 2011, 476) 
During the colonization of the Chaco, local indigenous communities were in fact the objects of significant photographic production as part of the development of a specific visuality of the region and its native inhabitants. This was partly the work of anthropologists, particularly that of the head of the Anthropology section at La Plata Museum, Robert Lehmann-Nitsche, and the museum's entomologist Carlos Bruch (Giordano 2004). Their images mostly reproduce the conventions of anthropometric photography, as can be seen in the following two images from 1899: the subjects are portrayed in standardized poses, in full frontal and side, naked, against an empty background that makes their physical features stand out, and with a measuring stick. ${ }^{4}$ In here we can see the centrality of phenotypic difference as a signifier of race, along with the construction of subjects as 'types'. What these photographs produced is a difference that could be objectively measured, quantified, and compared.

Figures 1 and 2: Lehmann-Nitsche and Brusch, photographs of Takshik toba boys at Buen Pastor Asylum, 1899.

This production of authorized visual knowledge was at times anticipated and at times parallel to the work of professional photographers like Guido Boggiani, Samuel Rimathé, Harry Grant Olds, and Hans Mann, who explored the Gran Chaco in search of images for the flourishing market of ethnic postcards and cartes de visite (Masotta 2005, Penhos 2005, Ponzinibbio 2014). ${ }^{5}$ Poole states that commercial photography was complementary - and, in many cases, undistinguishable - from anthropological photography: postcards and cartes de visite of indigenous people, as industrially produced image-objects, could be accumulated and displayed by the transnational bourgeoisie in the same way as any other commodity and collectable (1997). Their mass circulation and consumption in Argentina and abroad consequently allowed the dissemination of popular images of the chaqueño Amerindian as a commodified, nameless and de-historicized Other. These photographs mainly conformed to the primitivist tropes fashionable at the time - nakedness, painted faces, exotic animals and landscape - at times incorporating elements from anthropometric photography to their more aesthetic form (Alvarado and Giordano 2007). The following image, for example, reproduces the conventions of the group photograph, combined with the notion of untamed and irreducible savagery, expressed in the integration of the subjects into the setting (particularly the woman on top of the tree), and the colonial fetish of naked breasts. ${ }^{6}$ 
Figure 3: Early $20^{\text {th }}$-century postcard by an unidentified author portraying a toba group. Berlin Ethnological Museum.

It is important, in this brief account of the forms in which chaqueño Amerindians have been portrayed by visual anthropology and commercial photography, to avoid a monolithic view of the relationships between the photographer and the photographed. Complex negotiations could take place between the two, which at times resulted in consent and at times in refusal. Yet, it is unquestionably that these negotiations occurred in very unequal terms. In this sense, it is useful to read these images as what Mary Louise Pratt (1991) denominates 'contact zones', that is, 'social spaces where cultures meet, clash, and grapple with each other, often in contexts of highly asymmetrical relations of power' (33).

This concise genealogy of photography of the Chaco allows inserting Stern's work within a particular history of regionalized and racialized visuality, assessing it in terms of continuities and ruptures with this visual imaginary. Simultaneously, it moves away from readings that put too much emphasis on notions such as avant-gardism and authorship. Stern's first experience in the Gran Chaco was in 1958 in the city of Resistencia, on a contract with the National University of the Northeast. The institution was in the process of setting up an ethnographic museum and archive, to which Stern was to contribute with photographs of landscapes and communities. This two-month stay sparked her interest in the local indigenous population and culture: she photographed toba people living in the outskirts of Resistencia and Villa Ángela, as well as indigenous pottery, weaving and basketry. She returned to Resistencia in 1959, this time for a year and again hired by the University, which had decided to start a local art workshop and residency. An album of around fifty $6 \times 6 \mathrm{~cm}$ contact prints of photographs taken during his period, entitled Aborígenes en los alrededores de Resistencia, Chaco, 1959-1960 (Indigenous People in the Outskirts of Resistencia, Chaco, 1959-1960), was published as a result of this experience. As Priamo states, '[i]n their representation of habitat, customs, handicrafts and portraits some shots prefigure the subjects of her more extensive photographic record of 1964.' $(2005,164)$ These early images show how, from the very beginning, Stern was already departing from previous portrayals of chaqueño Amerindians by applying the principles of the Bauhaus and the Neues Sehen 
movement to these new photographic subjects and themes. For example, in 'Antonio Gómez, cacique toba, Resistencia, 1959-1960’ ('Antonio Gómez, toba cacique, Resistencia, 19591960') (Figure 4), all the elements of Stern's characteristic portraiture are present. We can see how the natural light in a forty-five degree angle above the subject focuses on his facial expression in order to present him as conveying what according to Stern were the attributes of a chief: wisdom and authority. This was coherent with her theory that portrait photography should capture the person's essence (Walsh 1952).

Figure 4: Stern, ‘Antonio Gómez, cacique toba, Resistencia, 1959-1960’, 1960.

Stern soon started to work on a proposal for a more ambitious venture, focusing on six areas of interest - landscapes, housing, clothing, lifestyle and living standards, facial features, and craft - but the implementation of the project was delayed due to her decision to decline public funding. Given the appalling conditions in which indigenous people were living due to state neglect and racism, it is possible to speculate that she feared restrictions would be imposed on the project by public institutions. Only in 1964, and after obtaining state funding from the Fondo Nacional de las Artes that guaranteed full artistic control, Stern went back to the Gran Chaco. She was now aged sixty-four. The project's rationale, initially intended to document the toba and mocoví populations in Resistencia and Villa Ángela photographed in previous visits, was expanded to encompass other localities and indigenous communities, not only in the province of the Chaco, but also in the provinces of Formosa and Salta. On her return to Buenos Aires after three months, Stern organized an exhibition with 189 images, which was initially presented in the San Martín Cultural Centre in Buenos Aires. For the white urban middle-class spectators of the exhibition, this was an opportunity to gaze at a remote, marginal area and population, of which they knew very little. The photographs subsequently circulated to cities in other Argentine provinces; specifically Resistencia, Santiago del Estero, La Plata, Mar del Plata, San Antonio de Areco and Adrogué. Stern also delivered talks in which she referred to the situation of the indigenous communities depicted. Although reception was positive, the series did not stand out amongst Stern's most celebrated works until recent years. ${ }^{7}$ Nonetheless, for her they were central in her oeuvre: an indication of this was the fact that they were the main series in Begegnungen mit Menschen: Das 
fotografische Werk von Grete Stern (Encounters with People: The Photographic Work of Grete Stern), her first major post-war European exhibition, from 1974. Private ItaloArgentine collector Matteo Goretti bought most negatives of the series - around one thousand - in $2001 .^{8}$

Stern's Chaco series has been hailed as one of the first examples of photographic essay in Argentina (Priamo 2005). Seen in this way, one could describe the particular narrative of the series as one in which the spectator is confronted with communities in the process of transculturation, with traditional practices and customs cohabiting with the transformations brought about by state and capital. Portrayals of weaving or of a man practicing marisca (foraging) show remains of old Amerindian lifestyles, while the overwhelming presence of Christianity (people attending religious services or holding bibles as a form of protection from the camera) or Western clothes indicate the impact of colonization. This impact is also visible in the depiction of people living in extreme poverty conditions: many subjects, particularly wichí, are wearing tattered garments, living in very precarious huts, or handworking the fields at a time in which mechanized agriculture was already common. Despite these tensions present in the photographs, Stern always refused to politicize her work and claimed: 'I have not gone into the subject myself. I simply photographed what I saw.' (Stern $2005,166)$ This statement reflects a willingness to move away from any possible reading of the images in terms of the rising emancipatory discourses of the Latin America Left of the time, and particularly those influenced by a Marxist indigenism in the vein of Mariátegui. This unwillingness to politicize can be seen in 'Fortín Lavalle, Chaco, 16 de julio de 1964. Velazco Rodríguez y Victorio López muestran la carta que le escribieron al gobernador de la provincia con algunos reclamos' ('Fortín Lavalle, Chaco, 16 July 1964. Velazco Rodríguez and Victorio López Show a Letter They Have Written to the Governor of the Province with some Complaints') (Figure 5). Although this is the image that most clearly documents the political situation of indigenous communities at the time, Stern's reluctance to provide the spectator with more information about the conflict is clear: the title never clarifies what kind of grievances the men are addressing and the reference to 'some complaints' is ambiguous. The medium-shot angle and the sunlight projected on the letter makes the content impossible to read for the spectator. Overall, the general feeling is that of detachment. 
Figure 5: Stern, 'Fortín Lavalle, Chaco, 16 de julio de 1964. Velazco Rodríguez y Victorio López muestran la carta que le escribieron al gobernador de la provincia con algunos reclamos', 1964.

Stern intentionally avoids denunciatory overtones and instead positions her work closer to a humanist ethos more concerned with universal moral values than with the concrete and localized present and past struggles of these communities. In other words, what drives her work is not a critical engagement with the coloniality of power but the possibility of building instances through which empathy with the photographic subjects can emerge. This is particularly visible in her portraitures, a type of photograph that features prominently in this series. Although she occasionally used $35 \mathrm{~mm}$ film, Stern took most of her Chaco photographs using mainly a Yashica-Mat $6 \times 6 \mathrm{~cm}$ camera. The preference for a medium format and monochrome color - images are black and white, except some that portray craft or face tattoos - is indicative that Stern's concern was careful composition rather than spontaneity. This is also symptomatic in the fact that she frequently used a tripod. Most of her portrait photographs accentuate the traits already present in her 1959-1960 images. In many cases, the subjects deliberately turn their face from the camera, as a statement of resistance to the disciplinary power of the gaze. In 'Villa Ángela, Chaco, junio de 1964. Hombre mocoví' ('Villa Ángela, Chaco, June 1964. Mocoví Man') (figure 6), the subject's face, turned towards the right, imposes itself over the spectator with an air of autonomy and selfpossession marked by the soft uniform light, the prominence of the figure and the absence of eye contact with the viewer.

Figure 6: Stern, 'Villa Ángela, Chaco, junio de 1964. Hombre mocoví’, 1964.

In 'Legua 15, cerca de Tres Isletas, Chaco, 14 de julio de 1964. Mujer toba con sombrero de totora' ('League 15, near Tres Isletas, Chaco, 14 July 1964. Toba Woman with Totora Hat') (Figure 7), the effect is further enhanced by the woman's smile: the low-angle shot and her facial expressions contrast with the objectifying tendency of anthropometric photography, thus humanizing the photographic subject. 
Figure 7: Stern, 'Legua 15, cerca de Tres Isletas, Chaco, 14 de julio de 1964. Mujer toba con sombrero de totora', 1964.

In both cases, the figure-ground organization is central: the background underscores the person's physical features, but contrary to anthropological photographs, in this case it is not phenotype as a signifier of race that comes to the fore, but rather the full expression of the face. It is precisely this expressiveness what allows affect to emerge. Through this, the images forefront the face as an interface in order to demonstrate the singularity of the subject, in contrast with the notion of the Amerindian as a representative of a racial 'type' in anthropometric photography. Rather than scopic ephistophilia, the indigenous face is engaged through formal concerns of composition. Although undoubtedly visual anthropology manifested certain attention to aesthetics, the break introduced by these images is profound in the sense that they construct the Amerindian primarily as an aesthetic figure rather than an object of scientific scrutiny. It is through this particular aestheticization, expressed in angles and framings reminiscent of the Bauhaus and the Neues Sehen, that these images resist their absorption by the hegemonic visuality of the chaqueño Amerindian.

The pre-eminence of subjectivity and affect in these images suggests the possibility of identification between spectator and photographic subject, which contrasts with the objectification and distancing of previous visuality. It would be possible to argue, in this sense, that they suggest a more ethical mode of representation of the chaqueño Amerindian. It is important to highlight, nonetheless, that this break is not exempt from certain problematic aspects, which emerge from the persistence of elements of normative discourse, particularly in titles and annotations. As a matter of fact, there is a complete lack of information regarding the photographed people, and only figures of authority, such as a religious ministers and caciques, are identified by name. The rest are mainly described in terms of their ethnic background, which in turn reinforces in the viewer the identification of the subjects according to the classificatory systems of anthropology. What we have here is an unresolved tension, since the formal composition of the photograph individualizes the portrayed subjects and encourages an aesthetic engagement through careful selection and staging of the visible, particularly the face as the site of affective life. Yet at the same time, this is counteracted by a captioning discourse that relapses into forms of classification, even typification, and therefore of 'denied coevalness' - which Johannes Fabian (1983) defines as 'a persistent and 
systematic tendency to place the referent(s) of anthropology in a Time other than the present of the producer of anthropological discourse.' (31) In this sense, Stern's images end up caught between the possibility of humanization and identification, and the prolonged presence of distance and othering. Additionally, in figure 6, the man's worn-out jersey foregrounds the notion of the Amerindian not only as a racial but also as a class Other, in line with the aforementioned double axis of the coloniality of power - racialization and proletarization.

It is convenient at this stage to refer to the parallels between photography and Foucauldian panopticism suggested by John Berger (1972), Simon Watney (1979) and Mirzoeff (2011). Watney, for example, highlights how photography can be understood as an apparatus in which the techniques that allow seeing produce the effects of power and discipline, particularly the visibility of those on whom the means of coercion are applied (170-71). Similar to the Panopticon, in photography the photographer is invisible behind the camera while what is seen by it renders it entirely visible. Victor Burgin and Christopher Pinney add that the conjunction of photography and anthropology involves the erasure of the presence of the photographers and of their cultures in order to stress re-production and repress production (Burgin 1982, Pinney 1992). However, one of the particularities of Stern's work on the Chaco is that it constitutes a material on which the discourses of visual anthropology and art interact in order to produce a different spectatorial effect. ${ }^{9}$ This can be connected to an aspect of the images to which I have referred in my previous discussion of Stern's humanist ethos: the primacy of universal moral preoccupations over social and political discourse. In fact, most critics have drawn on this in order to position the series in the conjuncture of specific ideas of ethics and aesthetics that sideline history - the history of colonial visuality - in favor of biography - Stern's life and work. This is perfectly exemplified in Priamo's introduction in Aborígenes del Gran Chaco:

Throughout her career she spontaneously combined high quality abstract compositions with motifs of poverty and marginalization [...] This should not surprise us since she came from an avant-garde background where the inclination for non-figurative or even geometrical compositions went hand in hand with a defense of the social function of art. She also had an instinctive sympathy for indigenous people [that] may have stemmed from her experience of exclusion and contempt in authoritarian Germany's mass 
enlistment in Fascism, producing in her conscious or unconscious identification with Argentina's aboriginal population. $(2005,165)$

The effect of this narrative is that the images are articulated mainly around Stern's figure, defined as the confluence of artistic modernity and ethical commitment. Both notions are essentially understood in European terms, given the references to the Bauhaus and Nazism. In consequence, the foundations of the Amerindian's otherness, rooted on a specific linkage between vision and coloniality, are hardly problematized, because Stern's figure prevails over other possible interpretations of the series. Given that, as mentioned before, authorship and biography emerge as the main mediations that structure the spectator's gaze, Stern's figure permeates all photographs with its presence. Simultaneously, like the anthropologist, this presence remains invisible, absent, erased. This paradox determines to a large extent the existence, circulation, and appropriations of these images. Foucault (1977) defines the 'author-function' as a particular construction that organizes a series of discourses under the author's name and defines the readings of the text, not just at the level of mere indication but instead providing the necessary coherence to signify a discursive unity. This idea can be applied to the case of Stern's images, resulting in the construction of the photographed subjects mainly as elements in a narrative that actualizes colonial accounts of exploration and encounter: the journey of the modern white/European towards the Other. In the end, the chaqueño Amerindian ends up being produced as an expression of aesthetic racial otherness that is positioned against Stern, an invisible yet overtly present figure in which notions of modernity and whiteness/European-ness converge. This significantly defines the consumption of the images, allowing the reproduction of this colonial fantasy of encounter in the viewer. Consequently, the extent to which Stern's images could allow a critical engagement with discourses of chaqueño indigeneity as a form of radical otherness are considerably diminished.

The last section of this article discusses this aspect in relation to contemporary Argentine photographers who have reinterpreted Stern's images of the Chaco. In recent years, many have turned their attention to indigeneity, in line with a growing interest in indigenous cultures in Argentina in general. This process can be partly interpreted as a result of Amerindian activism and the impact of transnational discourses of multiculturalism, which have led to a revision of ideas of national identity traditionally rooted on racial homogeneity and European-ness (Briones 2008, Grimson 2008, Segato 2007). Artists working on the 
Chaco like María Zorzón and Guadalupe Miles share an alleged aim to cast light on indigenous communities and their marginal situation, and to produce more ethical portrayals of indigeneity that at the same time challenge the foundations of colonial visuality (Giordano and Reyero 2009). Stern's work, in this regard, has been hailed as pioneer and as a fundamental reference when it comes to breaking with these modes of representation. However, as I will show, because the contradictions and paradoxes present in Stern's images are not problematized, these contemporary works end up reproducing the same tropes of colonial encounter and mastery that undermine possible challenges to the othering of indigenous people. The case of Miles, in particular, constitutes a compelling example of this. ${ }^{10}$

Miles has described her series of photographs of wichí, yowaja and nivaclé people from the Chaco region, produced between 2001 and 2005 and entitled Chaco, as significantly influenced by Stern's work in aesthetic and ethical terms. Not only does Miles aim to move away from colonial depictions of chaqueño Amerindians, but she also wants to raise attention to their situation of exclusion. The absence of captions or information in the series implies that the word 'Chaco' emerges as the only reference, evoking the fringes of the nation, in economic, geographical, and racial terms. Like Stern's, Miles's photographs at first seem to establish a critical dialogue with colonial representations of the chaqueño Amerindian. In the following images (figures 8 and 9), the preference for medium-close shots position the spectator in a situation of sufficient proximity as to allow them to appreciate close details, while at the same time preserving the distance. The use of a short shutter speed reduces the idea of movement, thus accentuating this sensation and giving the effect of an instant being captured by the camera. The lack of chiaroscuros, and the use of natural lighting and contrary to Stern's monochrome photography - of warm full-saturated tones, emphasizes intensity and vitality. The expressiveness of the subject also foregrounds affect and subjectivity. The playful and sensual poses, all carefully staged, break with the rational and objectivist gaze of early visual anthropology and, overall, the normative mediation of traditional depictions of indigenous people seems to be challenged. The press and critics have praised Chaco in this regard. For example, Karina Micheletto, writing for the newspaper Página/12, refers to it as "[a] work distant from the anthropological and compassionate approaches that work on indigenous themes usually provoke.' (2004) ${ }^{11}$ Juana Libedinsky described Chaco in the newspaper La Nación as 'far from stereotypes' (2004), while photographer Eduardo Gil stated: 'Miles was able to distance herself from a certain colonized 
gaze.' (2004) $)^{12}$

Figure 8: Miles, 'Untitled' (from Chaco), 2001.

Figure 9: Miles, 'Untitled' (from Chaco), 2001.

Beyond its innovative portrayal of indigenous people, a closer examination of Chaco reveals the persistence of the same limits that affect Stern's images, founded on the absence of problematization of the relationships between coloniality and visuality. The way in which the color of the child's skin under the sun mixes with the brownish water in figure 8 suggests a connection between the figure and nature: the Amerindian subject and landscape as one. The lighting and the color condense and transmit the vigor of sensual pleasure, which is also emphasized by the position of the body in the water. Near-nakedness and the use of a child model are also resonant of portrayals of indigenous peoples as noble savages, innocent and child-like. Thus, the series depicts the Amerindians as alluring and sensualized figures of otherness ontologically connected with nature for the pleasure and consumption of white audiences. Curator Rodrigo Alonso (2005) celebrates precisely this fetishization, without delving into the problematic aspect that it entails: 'an enigmatic and fascinating universe that is remote but not alien is revealed in Chaco, one that is populated by unknown beings, impregnated of seduction and sensuality.' $(34)^{13}$ The combination of exoticism with more familiar images of seductiveness ('remote but not alien') contributes to the impression of a voyeuristic experience in the viewer, which heightens the pleasures of looking - not far from the experiences of turn of the twentieth-century postcard. Indigeneity allows the white spectator to return to an original authenticity that has been lost or degraded by the experience of modernity and isolation. As Miles stated: '[the salteño Chaco] maybe connected me with certain vital issues or with something related to my childhood.' (quoted in Micheletto 2004) ${ }^{14}$ In sum, these photographs present an un-problematic portrayal of the wichi that sidelines any discussion of the coloniality of power in favor of a post-modern primitivist portrayal of indigeneity.

However, despite these problematic aspects, Chaco has the potential to at least suggest possible spaces in which to discuss race in contemporary Argentine art photography. A key to this interpretation is that sensuality in Chaco does not aim to allow the projection of 
hedonistic and erotic desires as Alonso claims, but rather to produce an ambivalent feeling. Miles deliberately brings together two seemingly incongruent notions, such as childhood and sensuality, in order to upset and challenge the spectator, in a gesture reminiscent of Sally Mann and Alessandra Sanguinetti. This can be seen in the child's sensual expressions of pleasure and the way her lips stand out from the rest of the image in figure 8 . This intensity and dynamism verging on the erotic in a photo of a child is precisely what ends up producing a disturbing feeling in the viewer. In figure 9 the same child is now almost nude and her face is out of sight. The composition centers on the only body part that is covered: her genitalia, barely hidden by the wet underwear. In this case, the child is both the subject and object of sensual enjoyment. The status of children as forbidden objects of desire implies that this ambivalence can affect the act of viewing, by creating a feeling of uneasiness. Figure 10 works in a similar way, as it focuses on a young man in an effete pose as he grabs his tattered red t-shirt.

Figure 10: Miles, 'Untitled' (from Chaco), 2001.

The photograph seems to reproduce established tropes of indigenous men as effeminate that, as Peter Wade (2009) points out, can be traced back to the times of European colonization. However, the image produces an effect that goes beyond the reproduction of this stereotype. The man's gesture and expression, and the fact that he is leaning against the wall as if the spectator were cornering him, give the impression of a veiled violent seduction. At the same time, his lips, which match the red of the t-shirt and the wall, stand out: like the child's genitalia, interpellate the spectator in a sensual way. His right hand is out of shot but nonetheless points towards below his waist and, perhaps, his genitals. The scene is erotic and inviting, yet aggressive, but in a subtle way. Finally, the presence of the ragged sports jersey interrupts the notion of indigenous people as living at one with nature, contrary to figures 8 and 9. Nonetheless, the tattered piece clothing does not signify poverty, as in Stern. These unexpected depictions of an indigenous man and child aim to seduce and perturb the gaze, and consequently, to de-naturalize the act of viewing - along with the whiteness that structures the main modes of representation and reception of Amerindians. To add to its subversion is the destabilization of the standardized pose as a technology of visuality 
inscribed in colonial representation.

By perverting the way in which these two indigenous people are being viewed, Chaco aims to provoke an interaction between the images and the viewer, wherein the possibility of a critical moment might come to the fore. However, the extent to which this critical discourse can eventually emerge is debatable. Like in Stern's images, the double axis of the coloniality of power, race and class, and the particular ways in which they have been deployed in Chaco, remains uncontested in decisive terms.

In this article, I have aimed to suggest a different approach to the study of Stern's Chaco work, one that reads the images in relation to a specific visuality of chaqueño indigeneity that was developed during the occupation of this region by the Argentine state. The analysis demonstrated that these photographs introduce a series of ruptures vis-à-vis this visuality through the creation of instances of empathic identification with the photographic subjects. The use of Neues Sehen techniques in portraitures allows the affective expression of subjectivity, which challenge the objectification and fetichization of early visual anthropology and postcards and, in turn, suggest a more ethical mode of representing indigeneity. Simultaneously, the relapsing into forms of classification and typification, and the author-figure - which have defined and continue to shape the particular forms of consumption and circulation of the images - question the extent of this ethical turn, given that the photographic subjects are still framed and perceived as figures of radical alterity. In this regard, there is an unresolved tension between aesthetic engagement and denied coevalness.

Despite continuities and ruptures with previous visual representations of chaqueño indigenous people, it is unquestionably that Stern's images have gone on to constitute a central moment in the visual imaginary of the Gran Chaco, given that they mark a profound shift towards a perception of the Amerindian as an aesthetic figure. The reading of Chaco by Guadalupe Miles allowed assessing how this aestheticization has been recuperated and appropriated by contemporary photographers. Miles's images also aim to establish a critical relationship with colonial portrayals of indigenous people but end caught up in similar problems as Stern's. This is mainly due to the reproduction of stereotypes of Amerindians as exotic and alluring creatures of nature, which again side-lines the discussion of the convergence of race and class in the production of coloniality. It could be argued that Chaco suggests a potential critical moment if we consider the ways in which the images perturb and seduce the white viewer, in the sense that the radical otherness of these representations of indigenous people could be de-naturalised by the perversion of the gaze. However, the extent 
to which this can allow the emergence of spaces for engaging critically with a history of colonial domination is, like in the case of Stern, inconclusive.

Acknowledgements: the author would like to thank Guadalupe Miles for granting authorization to reproduce some of her images in this article.

\section{References}

Alonso, Rodrigo. 2005. Quince x Quince. Fotógrafos x Críticos. Buenos Aires: Fundación Praxis.

Alvarado, Margarita, and Giordano, Mariana. 2007. Imágenes de indígenas con pasaporte abierto: Del Gran Chaco a Tierra del Fuego. Magallania 35(2): 15-36.

Berger, John. 1972. Ways of Seeing. London: Penguin.

Braunstein, José, and Miller, Elmer S. 1999. Ethnohistorical Introduction. In Peoples of the Gran Chaco, edited by E. S. Miller. Westport, CT: Bergin \& Garvey.

Briones, Claudia. 2008. La nación Argentina de cien en cien: de criollos a blancos y de blancos a mestizos. In Nación y Diversidad: territorios, identidades y federalismo, edited by José Nun and Alejandro Grimson. Buenos Aires: Edhasa.

Burgin, Victor. 1982. Photographic Practice and Art Theory. In Thinking Photography, edited by V. Burgin. London: Macmillan.

Combes, Isabelle, Villar, Diego, and Lowrey, Kathleen. 2009. Comparative Studies and the South American Gran Chaco. Tipití: Journal of the Society for the Anthropology of Lowland South America 7(1): 69-102.

Donaldson, Laura E. 2003. The Breasts of Columbus: A Political Anatomy of Postcolonialism and Feminist Religious Discourse. In Postcolonialism, Feminism, and Religious Discourse, edited by Donaldson and Kwok Pui-lan. New York: Routledge.

Edwards, Elizabeth. 1990. The Image as Anthropological Document. Photographic 'Types': The Pursuit of Method. Visual Anthropological 3: 235-58

Fabian, Johannes. 1983. Time and the Other: How Anthropology Makes its Object. Chichester: Columbia University Press.

Foucault, Michel. 1977. What is an Author?. In Language, Counter-Memory, Practice, edited by Donald F. Bouchard. Oxford: Blackwell. 
Gil, Eduardo. 2004. Sin mirada colonizadora. Página/12. October 1. http://www.pagina12.com.ar/diario/cultura/subnotas/41725-14319-2004-10-01.html (accessed June 1, 2012)

Giordano, Mariana, and Reyero, Alejandra. 2006. Retratos olvidados. La risa como límite en la fotografía etnográfica chaqueña. Actas del VIII Congreso Argentino de Antropología Social. Salta: Universidad Nacional de Salta.

Giordano, Mariana, and Reyero, Alejandra. 2009. La estetización del indígena argentino en la fotografía contemporánea. Ramona 94: 29-36.

Giordano, Mariana. 2004. De Boggiani a Métraux. Ciencia antropológica y fotografía en el Gran Chaco. Revista Chilena de Antropología Visual. 4: 365-90.

Giordano, Mariana. 2004. Grete Stern y el Chaco. Actas del XXIV Encuentro de Geohistoria Regional. Resistencia: IIGHI-CONICET.

Giordano, Mariana. 2012. Indígenas en la Argentina. Fotografías 1860-1970. Buenos Aires: El artenauta.

Gordillo, Gastón. 2005. Landscapes of Devils: Tensions of Place and Memory in the Argentinean Chaco. Durham, N.C.: Duke University Press.

Gordillo, Gastón. 2006a. En el Gran Chaco. Antropología e historias. Buenos Aires: Prometeo.

Gordillo, Gastón. 2006b. Places and Academic Disputes: The Argentine Gran Chaco. In A Companion to Latin American Anthropology, edited by Deborah Poole. Oxford: Blackwell.

Grimson, Alejandro. 2008. Diversidad y Cultura. Reificación y Situacionalidad. Tabula Rasa 8: 45-67.

Libedinsky, Juana. 2007. Lejos de los estereotipos. La Nación. July 1. http://www.lanacion.com.ar/921981-lejos-de-los-estereotipos (accessed January 18, 2013).

Lois, Carla Mariana. 2002. Miradas sobre el Chaco: una aproximación a la intervención del Instituto Geográfico Argentino en la apropiación material y simbólica de los territorios chaqueños (1879-1911). Fronteras de la Historia 7: 164-86.

Masotta, Carlos. 2005. Representación e iconografía de dos tipos nacionales. El caso de las postales etnográficas en Argentina 1900-1930. In Argentina a fines del siglo XIX y principios del XX. Buenos Aires: Fundación Telefónica; Fundación Espigas/ Fiaar.

Micheletto, Karina. 2004 Los wichí, con otros ojos. Página/12. October 1. http://www.pagina12.com.ar/diario/cultura/7-41725-2004-10-01.html (accessed January 14, 2013)

Mirzoeff, Nicholas. 2011. The Right to Look. Critical Inquiry 37(3): 473-96. 
Penhos, Martha Noemí. 2005. Frente y perfil. Fotografía y prácticas antropológicas y criminológicas. In Argentina a fines del siglo XIX y principios del XX. Buenos Aires: Fundación Telefónica; Fundación Espigas/ Fiaar.

Pinney, Christopher. 1992. The Parallel Histories of Anthropology and Photography. In Anthropology and Photography 1860-1920, edited by Elizabeth Edwards. New Haven and London: Yale University Press in association with The Royal Anthropological Institute, London.

Ponzinibbio, Joaquín. 2014. Estereotipos en la imagen del indígena chaqueño. Un pasaje de la pintura a la fotografía. Boletín de Arte del Instituto de Historia del Arte Argentino y Americano, Facultad de Bellas Artes - Universidad Nacional de La Plata, 14(14). http://sedici.unlp.edu.ar/bitstream/handle/10915/39916/Documento_completo.pdf?sequence= 1 (accessed December 11, 2014).

Poole, Deborah. 1997. Vision, Race, and Modernity: A Visual Economy of the Andean World. Princeton, N.J.: Princeton University Press.

Pratt, Mary Louise. 1991. Arts of the Contact Zone. Profession 91: 33-40.

Priamo, Luis. 2005. Grete Stern and the Paisanos of the Great Chaco. In Aborígenes del Gran Chaco: Fotografías de Grete Stern. Buenos Aires: Fundación Antorchas, Fundación CEPPA.

Quijano, Aníbal. 2000. Coloniality of Power and Eurocentrism in Latin America. International Sociology 15(2): 215-32.

Reyero, Alejandra. 2010. Difusión y consumo de la fotografía etnográfica chaqueña. Avá, 16: 231-44.

Segato, Rita. 2007. La Nación y sus otros. Raza, etnicidad y diversidad religiosa en tiempos de Políticas de la Identidad. Buenos Aires: Prometeo

Sierra, Marta. 2013. La frontera norte: Bordes estéticos y territoriales en el Noroeste argentino. In Heterodoxia y fronteras en América latina, edited by Andrés Kozel, Horacio Crespo and Héctor A. Palma. Buenos Aires: Editorial Teseo.

Stern, Grete. 2005. Aboriginal People of the Argentine Great Chaco. A Traveller's Tale. In Aborígenes del Gran Chaco: Fotografías de Grete Stern. Buenos Aires: Fundación Antorchas, Fundación CEPPA.

Viñas, David. 2013. Indios, ejército y frontera. Buenos Aires: Galerna; Santiago Arcos.

Wade, Peter. 2009. Race and Sex in Latin America. London; New York: Pluto Press.

Walsh, María Elena. 1952. Los desnudos faciales de Grete Stern. Sur 215-16: 146.

Watney, Simon. 1987. The Image of the Body. In Figures. Cambridge: Cambridge Darkroom. 
${ }^{1}$ Although this classification is problematic and has been challenged in recent years by some indigenous communities, it will be used as a reference, given that Stern also drew on it. Moreover, it is precisely the critical relationship between her images and the colonial intervention of the state expressed partly in scientific classification what is being discussed in this article.

${ }^{2}$ The proletarization of Amerindians, employed in very precarious terms by the local sugar and timber industries, was presented by the state as part of its civilizing mission, which also included the establishment of state settlements and Franciscan, Anglican and Mennonite missions and schools.

${ }^{3}$ Gordillo highlights the specifities of the Chaco region in state and state-sponsored scientific discourses during the nation-building period: 'Free of the nationalist narratives that firmly grounded Patagonia within national identities and of the cultural and archaeological sediment left by the relatively 'advanced' Andean civilizations of the northwest, the Chaco emerged as the most primitive of the internal frontier. In short, this was seen as the place whose native population was most radically removed from the modernizing and Europeanized ideal shaping the nation-state.' (Gordillo 2006b, 449)

${ }^{4}$ These photographs portray a group of takshik toba people who had been brought to Buenos Aires by theatre and circus entrepreneur José Podestá, who intended to ship them to Paris to exhibit them in the 1900 Universal Exposition. The national government refused authorization for this trip and ordered Podestá to return the Amerindians to the Gran Chaco. Lehmann-Nitsche regretted the decision since, he argued, it deprived the international community of the opportunity to do direct observation and study of this indigenous group. He decided to conduct the research himself, which was published in 1904 (Gordillo 2006a).

${ }^{5}$ Prior to the occupation of the Gran Chaco by the state, there had been lithographic and photographic images depicting the region and its native inhabitants (see Ponzinibbio 2014). However, this was not significant in quantity. Moreover, it is the convergence of state occupation, science and a transnational visual economy of race what makes the photographs produced during the turn of the twentieth century much more relevant to the study of visuality and indigeneity in the Gran Chaco.

${ }^{6}$ The work of Swiss anthropologist Alfred Métraux in the 1930s and 1940s introduced a series of breaks in anthropological discourses of chaqueño Amerindians, voicing a serious concern for the progressive disappearance of traditional forms of living of these communities. However, because for him the urgent task of visual anthropology was precisely to produce a visual archive of indigenous cultures before their definitive and irremediable absorption by hegemonic society, he continued to reproduce, in his writing and images, a notion of indigeneity as a fixed de-historicised form of alterity. As Gordillo states, 'Métraux was in many ways the epitome of the mid- $20^{\text {th }}$ Century ethnographer, primarily interested in topics such as mythology and shamanism. Issues of social and cultural change were not relevant to his analysis.' (Gordillo 2006b, 454)

${ }^{7}$ This recent interest can be partially explained not only by the central role that Stern occupies in Argentine photography, which has led to a thorough assessment of all her production, but also by an increasing visibility of Amerindians in the national imaginary, in contrast with previous conceptions of Argentina as a white/Europeanised country with a taken for granted indigenous absence.

${ }^{8}$ In 2012, Goretti was involved in a controversy around fifty-nine archaeological pieces of his collection that were suspected of having been stolen from Córdoba's Ambato Museum in 2008. A year later, he was eventually found non-guilty, as it could not be proven that these pieces were in fact the ones taken from the museum.

${ }^{9}$ Alejandra Reyero has examined this particular aspect in her study of the reception of Stern's photos by an indigenous community in Chaco. See Reyero 2010.

${ }^{10}$ Miles was born in Buenos Aires in 1971. She spent her childhood in Jujuy and Salta and later moved to Buenos Aires, where she studied photography and worked in advertising before starting her work on the Gran Chaco in the late 1990s. Although not a big name in the Argentine fine-art circuit, she is nonetheless a well-established artist and her work has been shown in numerous exhibitions in Argentina, Latin America and Europe. Some of her photographs are held in the collections of important Argentine museums and cultural institutions, such as the Fondo Nacional de las Artes or the Castagnino+macro Museum in Rosario. 
11 '[U]n trabajo alejado de las miradas antropológicas y piadosas que suele suscitar el acercamiento al tema aborigen'. This and all future translations are mine.

12 'Miles supo correrse del lugar previsible de cierta mirada colonizada'.

13 '[En Chaco] se vuelca, enigmático y fascinante, este universo alejado pero no ajeno, poblado por seres desconocidos, impregnados de seducción y sensualidad'.

13 '[El Chaco salteño] quizá me conectaba con ciertas cuestiones vitales o con algo que tenía que ver con mi niñez'.

Ignacio Aguiló is Lecturer in Latin American Cultural Studies at the University of Manchester. His research examines the intersection of race, nation and culture in contemporary South America. He is currently preparing a book on the impact of the 2001 Argentine Crisis on national narratives of whiteness and racial homogeneity, focusing on literature, cinema, art and photography, and popular music. 